\title{
Early Music Printing in German-Speaking Lands
}

Edited by

Andrea Lindmayr-Brandl, Elisabeth Giselbrecht

and Grantley McDonald

First published 2018

ISBN: 978-1-138-24105-3 (hbk)

ISBN: 978-1-315-28145-2 (ebk)

Chapter 9

\section{The cult of Luther in music}

Grantley McDonald

(CC BY-NC-ND 4.0)

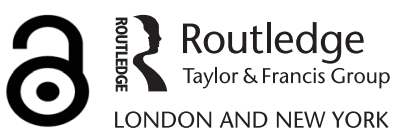





\title{
The cult of Luther in music ${ }^{1}$
}

\author{
Grantley McDonald
}

Several studies have confirmed the truism that the Reformation could not have taken place if not for the easy availability of print. The triangular relationship between print, the Reformation, and music is less obvious. The sudden demands of the Reformation on the presses of Germany and on the attention and resources of German readers and book buyers temporarily suppressed the production of certain kinds of printed musical sources. For example, while seventeen editions of the missal, most containing music, were printed for the diocese of Passau between 1491 and 1522, none were produced after this period. ${ }^{2}$ The presence of similar patterns in other German dioceses suggests that this was not due simply to coincidence or a saturation of requirements. Rather, the kinds of music being printed changed in response to the onset of the Reformation. Beginning in 1524, there was an explosion of editions providing music for the Lutheran rite: liturgical books for the use of the clergy, monophonic hymn books for the use of the congregation, and books of polyphony for the choir. Moreover, Lutheran and Roman Catholic controversialists alike used music to spread propaganda, as Rolf Wilhelm Brednich, Rebecca Wagner Oettinger and others have shown. ${ }^{3}$

Printed material tends to be of two kinds: ephemeral (or occasional), and archival, that is, material intended to be consulted more than once. Print increased the availability and quantity of both kinds of source, ephemera particularly strongly. ${ }^{4}$ Since propaganda is usually topical and timely, it is naturally somewhat ephemeral. However, collectors who preserved ephemeral material for later consultation helped it cross over into the realm of the archival. It is principally the fortuitous activity of such early collectors that has preserved ephemeral pamphlets until our time. ${ }^{5}$

The present paper will examine five ephemeral or occasional editions containing music that have hitherto escaped detailed examination. As we shall see, they vividly reflect the ways in which printed music helped form the public image - or rather, images - of Martin Luther. These pieces reflect on several landmarks in Luther's life as well as on the religious reforms he provoked. The first, Ad Martinum Lutherum captivum lamentatio, is a reaction to Luther's apparent abduction to the Wartburg in 1521. The second, Epithalamia Martini Lutheri Wittenbergensis, decribes Luther's marriage in 1525 as the latest in a series of outrages against the monastic vows to which he had sworn. The third, Eyn erschreglicher und doch widderumb

1 For Elisabeth Giselbrecht, in fond memory of our library adventures. Research for this paper was made possible by funding from the Austrian Science Fund (FWF) for the project P24075-G23.

2 Weale and Bohatta, Bibliographia liturgica, 131-136.

3 Brednich, Liedpublizistik; Wagner Oettinger, Music as Propaganda.

4 Eisermann, 'Auflagehöhen von Einblattdrucken', 143.

5 Griese, 'Sammler und Abschreiber'. 
kurtzweylliger und nutzlich gesangk, depicts Luther as the tool of Satan and his demons, who rejoice at his attacks on the authority and traditions of the Roman church. The fourth and fifth pieces, Leonhard Kettner's Nu hört jr Christen newe meer and Caspar Othmayr's Mein himlischer vatter, set Luther's last words to music. These two pieces, written within a few months of Luther's death on 18 February 1546, depict his last moments as suffused with pious tranquillity, in contrast to the stories spread by Roman Catholic apologists, in which the dying Luther was described as tortured by demons. These musical pamphlets present highly partisan interpretations of Luther, depicting him either as a saint or as a tool of the devil. The music thus serves a similar function to visual images that were likewise spread through the medium of print, such as Hans Baldung Grien's woodcut of Luther as an inspired, prophetic saint (Figure 9.1), or the title woodcut to a polemic by Petrus Sylvius, which depicts Luther as an accomplice of the devil (Figure 9.2).

These pieces contain several recurrent details that reveal much about the authors' motivations. The persistent imagery of saints and demons in the texts provides insight into the perceived cosmic consequences of Luther's rebellion. These pieces are written in various musical styles and genres, with analogies in the various registers of Reformation debate, which extended from learned and reasoned theological argumentation to abusive namecalling. The variety of musical genres, and the form in which the music is presented - either as broadsheets, pamphlets or individual pieces within collections of polyphony - suggests

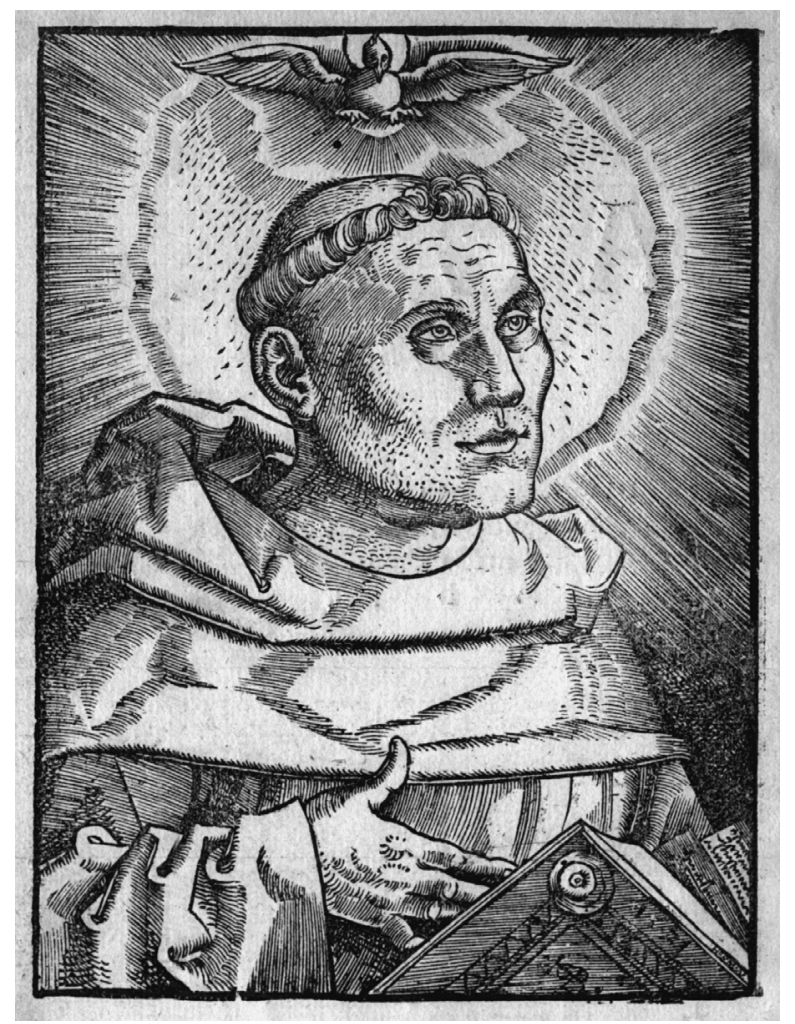

Figure 9.1 Hans Baldung Grien, Luther as an Augustinian friar, from Acta et res gestae, D. Martini Lutheri, in Comitijs Principum Vuormaciae, Anno M D XXI. [Strasbourg]: [Johann Schott], [1521], (VD16 ZV 62), fol. A1 ${ }^{\mathrm{v}}$

Source: München, Bayerische Staatsbibliothek, Res/H.ref. 750 k 


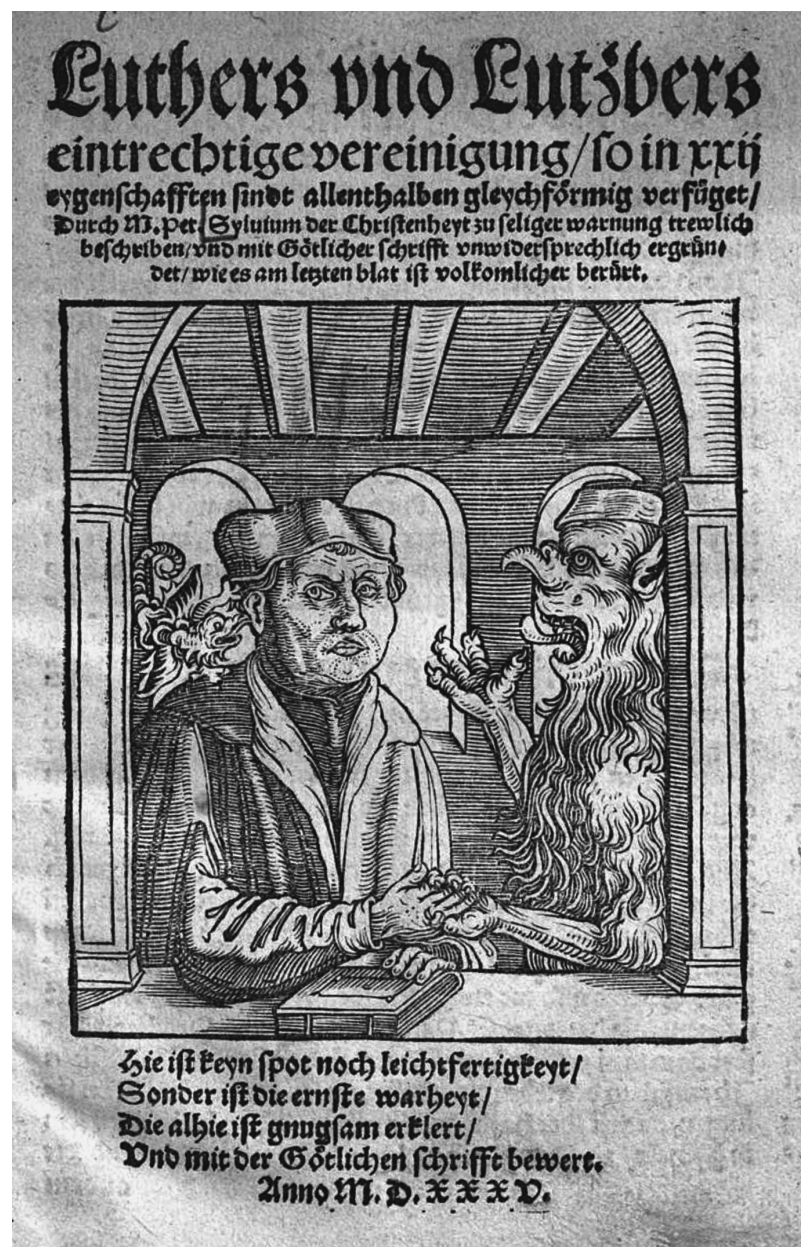

Figure 9.2 Title page from Petrus Sylvius, Luthers vnd Lutzbers eintrechtige vereinigung. [Leipzig]: [Michael Blum], 1535 (VD16 P 1310), fol. A1 ${ }^{\mathrm{r}}$

Source: Staatliche Bibliothek Regensburg, 999/4 Theol.syst.675(3)

conclusions about the intended audience for these pieces, and the circumstances of their performance.

\section{Ad Martinum Lutherum captivum lamentatio}

The first piece we shall consider is a polyphonic lament on the supposed abduction of Luther in early May 1521. After Luther was placed under imperial ban at the Diet of Worms, Duke Friedrich the Wise of Saxony had a band of men intercept his party in a feigned attack. Luther was then brought to safety in the Wartburg, a fortress near Eisenach, where he would live in disguise for the next ten months. As news of Luther's apparent abduction spread in May 1521, his supporters reacted with horror, uncertain of his fate. On 17 May 1521, Albrecht Dürer wrote in his diary:

I don't know if he is still alive, or if they have murdered him. He has suffered this fate on account of Christian truth and because he punished the unchristian papacy [...]. O God, if 
Luther is dead, who will proclaim the Gospel to us so clearly? O God, what might he yet have written for us in ten or twenty years? O you pious Christians, help me to mourn this Godgiven man properly, and pray that God send us another enlightened man. ${ }^{6}$

An anonymous poet expressed similar sentiments in the following Latin verses:

Heu heu quae nobis te sors doctissime ademit?

Quae te praehendit invida?

Quis te livor edax rapuit dulcissime? Quid sic

Martine anhelos deseris?

Sicne tibi servata fides, servataque iura?

Hei veritas quid sustines?

Parce precor praedae raptor, satis est rapuisse.

Heus parce, parce occidere.

Alas, what fate has taken you, o learned man, from us?

What envious fate has grasped you away?

What destructive spite has taken you, o sweetest man?

Why do you thus desert your fervent followers?

Is this how you preserve your faithfulness, and observe your vows?

Alas o truth, what a blow have you taken!

O captor, show mercy to your prey, I pray; it is enough to have taken him;

Spare, o spare from taking his life.

The title of the poem, 'A lamentation for the captive Martin Luther', is subtly undercut by the choice of metre. Laments were normally written in elegiac couplets or hexameters. By contrast, this poem is written in a rare metre, the second Pythiambic, which comprises distichs of a hexameter followed by an iambic dimeter. This metre is generally found not in laments but in epodes, a species of invective poem. Heu heu quae nobis te sors expresses not merely loss. The grieving poet blames Luther for vanishing, characterising this as a betrayal of the trust his followers had placed in him; Luther's disappearance had led to a state of civil disquiet comparable to that lamented by Horace in his own bitter epodes. This subtle choice of metre, chosen carefully to reflect the poet's conflicted emotional state, and the classicising Latin diction (for example, the collocation 'livor edax' is borrowed from Ovid) suggest that the poem was probably written in the humanist milieu of the universities or urban sodalities, from which Luther drew much of his early support. ${ }^{7}$

An anonymous polyphonic setting of this poem for four voices was printed on a broadsheet (Figure 9.3, Example 9.1). ${ }^{8}$ The music is set in the third and fourth tones, widely acknowledged in the sixteenth century as appropriate for lamentation. The quality of the music is consistent with the proposed origin of the poem; the writing is generally competent and at times quite effective, but is not the work of a first-rate composer. The music appears to have been written specifically for this text. At some points the word-setting is relatively syllabic, and fits closely with the music. If the piece were a contrafact, then the text of the model would necessarily have been written in the same unusual metre, and cast in similar units of sense. Given the rarity of the metre, this is perhaps unlikely.

6 Dürer, Tagebuch, 1:170-171: 'Und lebt er noch oder haben sie jn gemördert, das ich nit weiß, so hat er das gelitten umb der christlichen wahrheit willen und umb das er gestrafft hat das unchristliche pabstumb [...]. O Gott, ist Luther todt, wer wird uns hinfurt das heilig evangelium so clar fürtragen! Ach Gott, was hett er uns noch in 10 oder 20 jahrn schreiben mögen? O ihr alle fromme christen menschen, helfft mir fleissig bewainen diesen gott geistigen menschen und ihn bitten, das er uns ein andern erleuchten mann send.' See also Steiff, 'Entführung Luthers', 210-212. All translations are my own.

7 Steiff, 'Entführung Luthers', 211.

8 D-Tu Ke XVIII $4.2^{\circ}$ Nr. 20, vdm 159. 


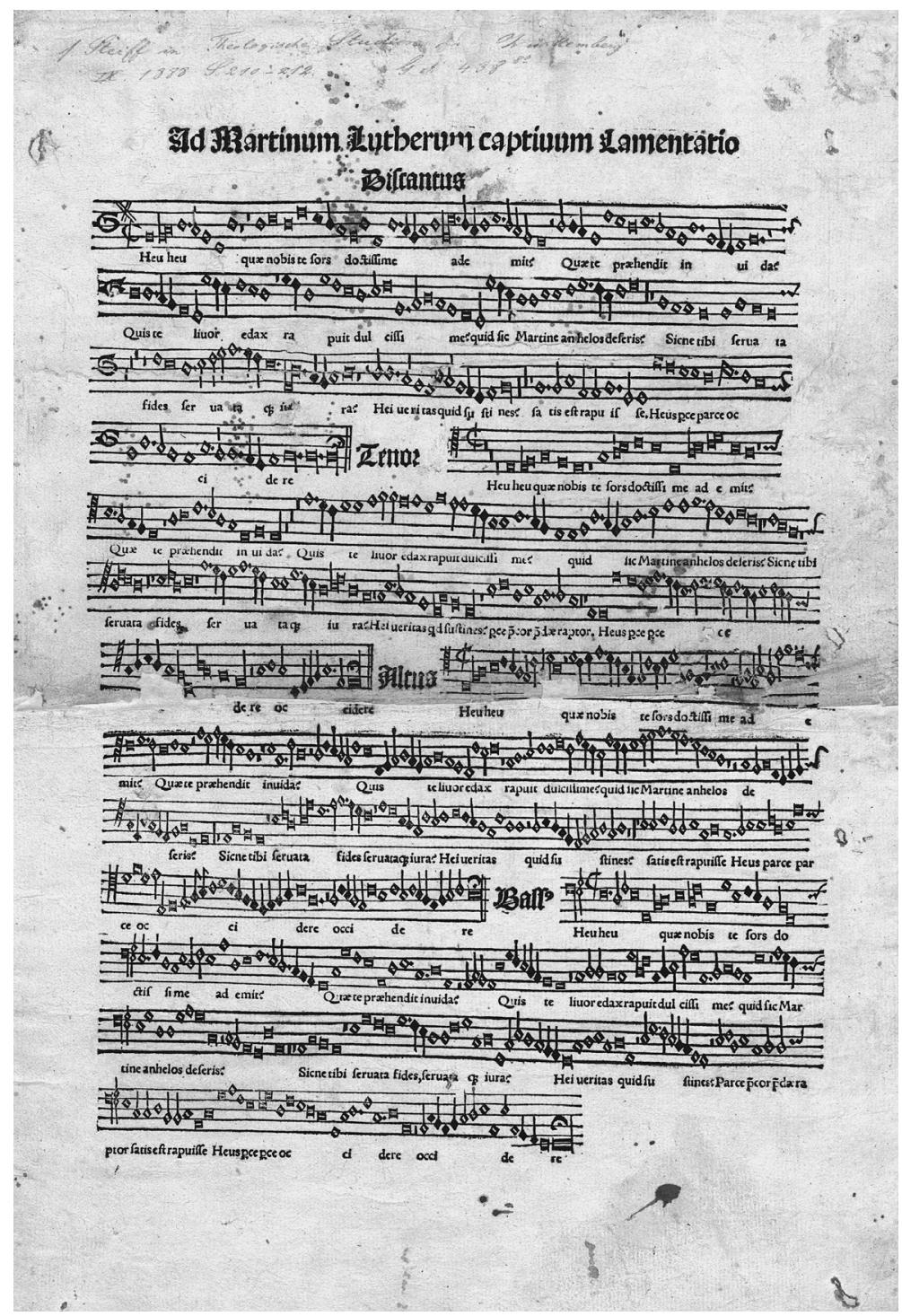

Figure 9.3 Ad Martinum Lutherum captivum lamentatio. [Strasbourg]: [Johann Knobloch the Elder], [c.1521], (vdm 159)

Source: Universitätsbibliothek Tübingen, Ke XVIII 4.2 ${ }^{\circ}$ Nr. 20

Neither the date nor the printer's name are mentioned on the sheet, but on the evidence of the type, the edition has been assigned to Johann Knobloch of Strasbourg. ${ }^{9}$ This does not necessarily mean that the piece was written in Strasbourg; Knobloch could have pirated a sheet printed somewhere else. Nevertheless, the piece was evidently written during Luther's time on the Wartburg (May 1521 to February 1522), probably early in that period, before it became clear that Luther was still alive. The notes are printed from woodcut. Except in the case of books consisting entirely of mensural notation or chant, woodcut was still the most common way of printing music in Germany at this time. While Dürer expressed

9 Röckelein et al., Die lateinischen Handschriften, 80-81. 
his distress in private, the medium of print allowed this poet and composer to publicise Luther's suspicious disappearance, to reflect on its significance, to express their personal reaction to this event, and even, as the last couplet would have it, to try to influence the outcome of the situation.

The only known copy of this broadsheet survived because it was bound into a manuscript by Conrad Hager, pastor of Renningen during the Reformation, whose collection represents one of the most important sources of the broadsheets now preserved in the university library in Freiburg. ${ }^{10}$ The sheet was obviously used; at a couple of points, notes that are unclear in the woodcut have been touched up in ink, such as the broken stem on the first minim in the discantus. Collectors such as Hager evidently valued such ephemera even after their 'news content' was no longer relevant. Preserving evidence of reactions to the reformer's life was a way of participating in the event as it happened, and commemorating it after it was past.

\section{Epithalamia Martini Lutheri Wittenbergensis}

The second piece we shall examine was written in response to Luther's wedding in 1525. When urged by his friends to marry, Luther protested that he, as an outlaw under imperial ban, might be taken and executed at any time. Such uncertainty was an unfair burden to expect a wife to bear. When a group of fugitive nuns appeared in Wittenberg shortly after Easter 1523, Luther was able to arrange marriages for all except one, Katharina von Bora. At last he was prevailed upon to marry her, and the ceremony duly took place on 13 June 1525. Cranach's workshop created a series of double portraits of Luther and Bora in order to emphasise the lawfulness of the wedding. ${ }^{11}$ To the enemies of the Reformation, the marriage of an Augustinian friar to a runaway Carthusian nun provided yet more proof that Luther had abandoned ecclesiastical discipline at the urgings of his intemperate passions. Lyndal Roper has recently shown that a fascination with Luther's appetites, both culinary and sexual, played an important role in the creation of his public image on both sides of the confessional divide. ${ }^{12}$

Luther's opponent Hieronymus Emser, shocked by his marriage to Bora, wrote a collection of three satirical epithalamia (wedding songs) for Luther and for Johannes Hess, Lutheran preacher at St Mary Magdalene's church in Breslau, who married Sara Jopner on 8 September $1525 . .^{13}$ The first poem in the collection, subtitled 'Hymn of the groomsmen' (Hymnus paranymphorum), is set to music (Figure 9.4). ${ }^{14}$ Emser's 'Hymn of the groomsmen' ironically celebrates the marriage of Luther and Bora, and includes a jubilant enumeration

10 Huguitius Ortulus grammatice, D-Fu Mc 6 (olim Q 161); Steiff (1888), 211; Brinkhus, 'Bücherstiftung Hagens', esp. 15-16; Röckelein et al., Die lateinischen Handschriften, 80.

11 Leppin and Schneider-Ludorff, Luther-Lexikon, 117.

12 Roper, 'Martin Luther's Body'.

13 Köstlin, 'Johann Heß', 218-219.

14 EPITHALAMIA \| MARTINI LVTHERI Vuittenbergensis, IOANNIS HES||SI Vratislauiensis, ac id genus nuptiatorum ([Dresden]: [Hieronymus Emser], [c.1525]), vdm 738. Some sources (including VD16) attribute this collection to Johannes Cochlaeus, but Cochlaeus attributed it to Hieronymus Emser; see Johannes Cochlaeus, COMMENTARIA || IOANNIS COCHLAEI, DE ACTIS || ET SCRIPTIS MARTINI LVTHERI SAXONIS [. . .] (Mainz: Behem, 1549), VD16 C 4278, 118: '[Lutherus] omnia ista dissimulans, Monialem duxit uxorem, ac laetas celebrauit publice nuptias, incoestu \& uotifragio sacrilegas, ac tot milibus occisorum funestatas. In quas sane nuptias satis elegans (ut amoeni erat uir ingenij) aedidit carmen Hieronymus Emserus. Quod \& Quatuor vocum concentu decorauit [.. . He cites from the Epithalamia]. Hęc pius Emserus, in quem multi iuuenes Poëtę Vuittebergenses iampridem frustra conspirauerant. In mortem enim usque constantissime uir ille piam patrum religionem contra eos defendit.' Further, see Ruland, 'Epithalamia Martini Lutheri', Wiedemann, Johann Eck, 557-565; Clemen, 'Beiträge zur Lutherforschung 3', 113-114. 


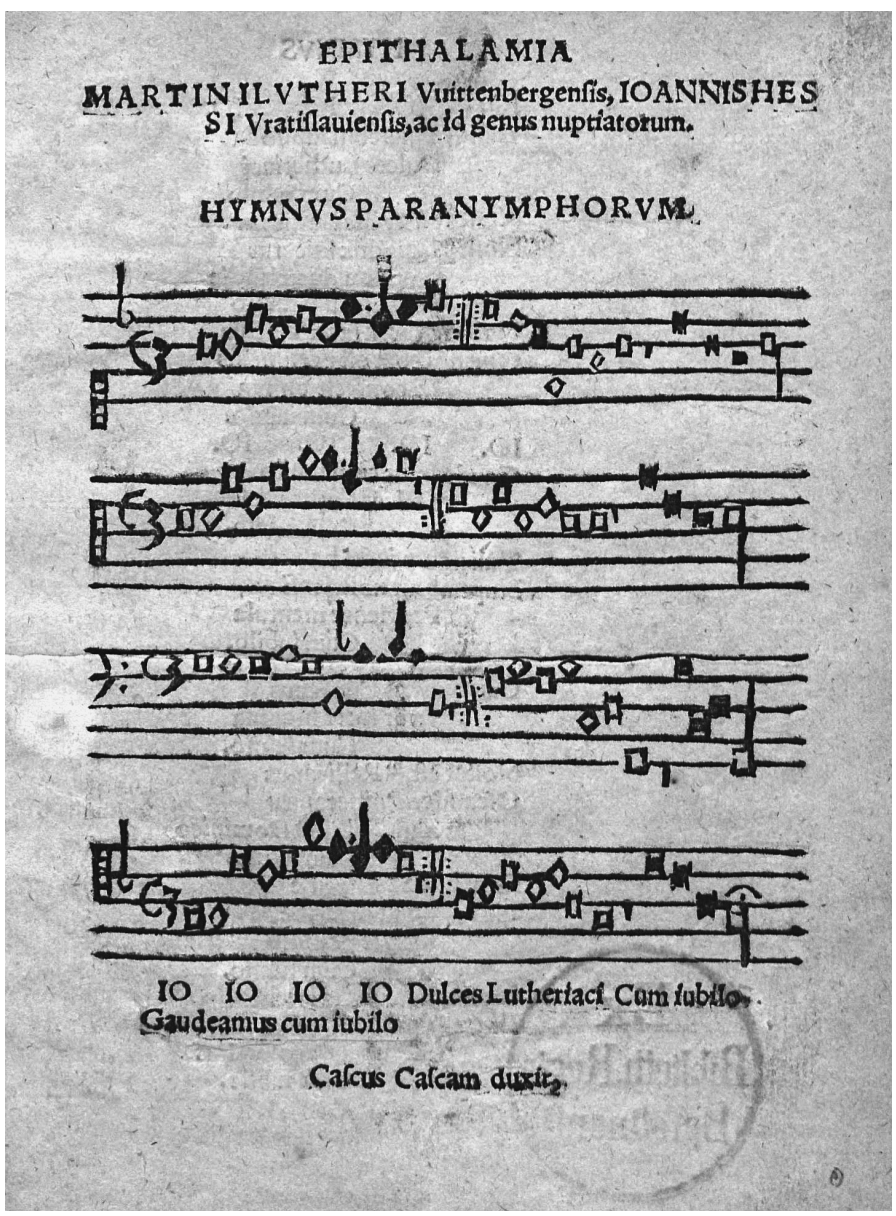

Figure 9.4 Epithalamia Martini Lutheri Wittenbergensis. [Dresden]: [Hieronymus Emser], [c.1525] (VD16 ZV 21361, vdm 738), fol. A1 ${ }^{\mathrm{r}}$

Source: Forschungsbibliothek Gotha, Schloss Friedenstein, Cant.spir $8^{\circ} 01323$

of other married Protestant clergy, including Hess, Pellicanus and Bugenhagen. Yet Emser satirically undercut the event and questioned the motivations of its participants. Surpassing the good-natured ribaldry characteristic of the classical epithalamium, the groomsmen sing that Luther acted only to satisfy his itching member ('pruriente mentula'), and rejoice that they were now free to indulge in every kind of unspeakable wickedness ('licet nobis $\mid$ Omne nephas'). This wild abandon is seen as the ultimate outcome of Luther's disdain for authority: 'Let kings, popes and emperors disapprove [...], let us laugh even at the saints of Christ, and destroy their images' ('Infamare licet reges | Papamque cum Caesare [...] | Sed et ipsos irridemus | Christi sanctos, et delemus | Eorum imagines'). Luther and Bora mocked the monastic discipline to which they had earlier sworn: 'Hence o cowl, farewell o habit, Bye-bye prior, guardian, abbot, along with your obedience' ('I cuculla, vale cappa | Vale Prior, Custos, Abba |Cum obedientia'). This wedding chorus is set to stirring music in a catchy homophonic style, and each stanza concludes with the cry, 'with joy' ('cum iubilo'), in an arresting hemiola pattern (Example 9.3).

The second poem in the collection is in mock-heroic hexameters. It begins with an invocation to the Muse, who is to tell of the strange marriage of Luther, this 'insane monk, 
who mingles sacred and profane, who stirs up crowds and riots, who subverts every norm of order and the faith' ('[...] Insano monacho, qui miscet sacra profanis, | Qui turbas, motusque ciet, qui subruit omnem | Ordinis, \& fidei normam [...]'). This, according to Emser, was the result of Luther's dangerous ambition: 'He farts at the highest peaks, and touches the sacred heights' ('[ . . ] oppedit et ipsis | Verticibus summis, et sancta cacumina tangit'). The scatological humour of this poem is not simply gratuitous or puerile, but expresses vividly the horror aroused by Luther's sacrilege, as Piotr Wilczek has argued. ${ }^{15}$ The third poem calls on the Furies to attend the wedding of Hess.

Emser's 'hymn of the groomsmen' is not an entirely new work, but is based on the Rhythmus die divi Martini pronunciatus ('rhythmical song performed on St Martin's day') by the Bolognese humanist Antonio Urceo Codro (1446-1500):

Io Io Io Io,

Gaudeamus Io Io,

Dulces Homeriaci, Io Io,

Noster vates hic Homerus,

Dithirambi dux sincerus

Pergraecatur hodie, Io Io.

Io, io, io, io,

Let us rejoice, io, io,

Sweet disciples of Homer, [...]

This our poet Homer,

The genuine leader of the dithyramb,

Today rejoices with Greek abandon [. . .].

The refrain Io io and the reference to the dithyramb indicate that the song was intended as a kind of bacchanal. ${ }^{16}$ Codro's Rhythmus was popular in Germany and Poland, and was reprinted at least six times north of the Alps. Some of the German editions contain a fourvoice setting that may have become attached to the poem only once it had left Italy (Example 9.2). ${ }^{17}$ Codro's Rhythmus was particularly popular at Wittenberg in the early sixteenth century. It was reprinted there twice $(1511,1513)$, and was sung at the thirtieth birthday party of the Wittenberg humanist Christoph Scheurl in November 1511, where the guests included Georg Spalatinus. ${ }^{18}$ It also formed the basis for a dithyramb by Jacob Locher on the election of Charles V in $1519 .{ }^{19}$

15 Wilczek, (Mis)translation and (Mis)interpretation, 79-101, esp. 88.

16 Creizenach, 'Das "Gaudeamus"', 204.

17 Antonio Urceo Codro, In hoc Codri volumine \| hec continentur. \| Orationes. seu sermones $\|$ vt ipse appellabat. \|E Eistole || Silue || Satyre || Egloge || Epigrammata (Venice: Liechtenstein, 1506), USTC 990166, fols. $66^{r-v}$ (no musical notation); ANTHONII CODRI VRCEI \| Rhythmus die diui Martini $\|$ pronunciatus [. . .], ed. Herman Trebelius (Wittenberg: Grunenberg, 1511), vdm 95; RHYTMVS CODRI VRCEI DIE \| DIVI MARTINI PRONVNCIATVS ([Worms]: [Gregor Hofmann], [c.1542-1553]), vdm 94; Antonij Codri Vrcei rhythmus \|l die diui Martini pronunciatus [...], ed. Hermann Trebelius (Wittenberg: Grunenberg, 1513), vdm 93; RITHMVS CODRI VRCEI POETE ET ORA |TORES VNDEQVAQVE DOCT|ISSIMI IN DIE DIVI MARTINI \| PRONVNCIATVS (Erfurt: Hans Knappe the Elder, 1514), vdm 645; RHYTHMVS CODRI FESTIVISSIMVS. \| CARMEN MORI VRBANSSIMVM. I || LVSVS CAMICZIANI VERISSIMVS (Leipzig: Melchior Lotter, 1519), VD16 ZV 15128; not in vdm; no musical notation; EXHORTATIO \| GVILIELMI BREYDSCHNEIDERII, IVRE $=$ |consulti Herbipoleñ. in amoeniora stu=|dia [. . ] ([n. p.]: [n. p.], 1526) VD16 ZV 2455; not in vdm; no musical notation; ANTONII CO\|DRI VRCEI [ . . . ] opera, quae extant, omnia [. . .] (Basel: Henrich Petri, 1540); not in vdm; no musical notation, 415-420. In the Zwickau copy of Frank's edition (VD16 ZV 15128), music is added by hand; see Clemen, 'Andreas Frank von Kamenz', 107. I could not locate any copies of the following edition listed in Estreicher et al., Bibliografia polska, 32:63: Hymnus faceciis, urbanitate et hilaritate plenus, in honorem Bachi et potatorum omnium ab Autore editus ([Vienna? Kraków?]: Hieronymus Vietor, 1528).

18 D-Ngm Cod. 306, fol. 92'; digest in Bauch, 'Zu Christoph Scheurls Briefbuch', 422.

19 Heider, Spolia vetustatis, 206-208. 
Emser's parody follows Codro's original quite closely, assimilating its dithyrambic refrain $(I o, i o)$, its metrical structure (the so-called Stabat Mater strophe) and the triple rhythm of the musical setting, though the music itself is different (see examples 9.2 and 9.3):

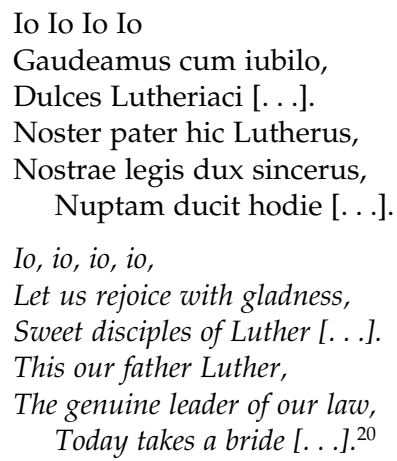

The idea of writing a parody of Codro's Rhythmus may have occurred to Emser because of the association of St Martin's day and Martin Luther, or because of the popularity of Codro's Rhythmus at Wittenberg. The idea of adapting Codro's poem as an epithalamium may likewise have suggested itself to Emser because a poem celebrating the wedding of Georg Schiltel was included in the 1519 Leipzig edition of Codro's text.

The inclusion of musical notation in Emser's pamphlet suggests that the piece was intended to be sung, probably in a convivial gathering of students or humanists such as the dulces Homeriaci bidden to sing Codro's Rhythmus. Ingrid Rowland has shown that groups of humanists sometimes participated in spirited drinking sessions, during which they would recite and improvise satirical and often shockingly obscene poems criticising the sexual excesses of the clergy. ${ }^{21}$ Emser's Epithalamia may have been sung at just such a gathering. Once printed, such poems could be read and sung at multiple gatherings in different places, thus forging group identity through the recognition and abuse of a common enemy.

The sole independent edition of Emser's Epithalamia comprises a single sheet of poorquality paper in quarto format. The music is printed from woodblocks, legibly but without much elegance. There is little attempt to align the voice parts. This was evidently not intended as a luxury edition. The edition is unsigned, but its types belonged to Emser's press in Dresden, which produced a number of polemical pieces against Luther in the 1520s, including another one with music that protested against Luther's rejection of St Benno. ${ }^{22}$

Emser's satires on the weddings of Luther and Hess were evidently quite popular. The text (without the music) was reprinted as an appendix to a 1527 edition of the correspondence between Luther and Henry VIII, edited by Johann Eck. ${ }^{23}$ The entire

20 The dependence of Emser's Hymnus paranymphorum on Codro's Rhythmus was pointed out by Creizenach, 'Das "Gaudeamus"', 204; see also Malagola, Antonio Urceo, 410-412.

21 Rowland, 'Revenge'.

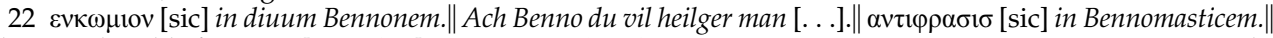
Ach Luter du vil bößer man ([Dresden]: Emser, 1524), vdm 167. See Wagner Oettinger, Music as Propaganda, 52-53, 81-88, 129, 205, 213-214, 231.

23 EPISTOLA || MARTINI LVTHERI AD HENRI||CVM.VIII.ANGLIAE AC FRAN=|ciae Regem etc. In qua ueniam petit eorum $\|$ quae prius stultus ac praeceps in eundem $\|$ regem effuderit: offerens pali $=\|$ nodiam se cantaturum. | RESPON||SIO DICTI INVICTISSIMI ANGLIAE \| ac Franciae regis [. . .] || EPITHALAMIA festiua in Lutherum, Hessum et id genus nuptiatorum, ed. Johann Eck (Ingolstadt: [Peter Apian and Georg Apian], 1527), VD16 L 4622 , fols. D $1^{\mathrm{r}}-8^{\mathrm{r}}$. The gathering containing the Epithalamia is absent from many of the copies I inspected. 
pamphlet, including the music, was also copied into a manuscript collection of antiReformation propaganda written by Lorenz Truchsess von Pommersfelden (1473-1543). ${ }^{24}$ Lother Mundt has argued convincingly that the Epithalamia influenced Simon Lemnius' Monachopornomachia. ${ }^{25}$ Indeed, the poems would be cited in anti-Lutheran propaganda for centuries to come. ${ }^{26}$

\section{Eyn erschreglicher und doch widderumb kurtzweylliger und nutzlich gesangk}

The third edition we shall consider is another satirical piece, 'A frightful and yet amusing song of the Luciferian and Lutheran church', published as part of a new year's message for 1526 by the Roman Catholic controversialist Petrus Sylvius. ${ }^{27}$ Sylvius' song was a direct response to two contrafacts that appeared in the wake of the Diet of Worms. In 1521 or 1522, one of Luther's supporters wrote the contrafact Invicti Martini laudes intonant Christiani ('Christians sing aloud the praises of the invincible Martin'), a parody of the Easter sequence Victimae paschali laudes, which was to be sung to the same melody. ${ }^{28}$ Sylvius objected to the fact that this poem implicitly placed Luther on the same level as Christ. He also noted that another parody, this time of the vernacular Easter Leise Christ ist erstanden, was sung at Nuremberg in 1524, to the same melody as the original:

Martinus hat gerathen/ man sol die pfaffen brathen.

Die mönnich vntterschüren/ Die Nonn inß. N. füren. kyrioleiß. ${ }^{29}$

Hoffmann von Fallersleben, Gaudeamus igitur, reports having seen this text in a sixteenth century manuscript; its location is now unknown.

24 D-Mbs Clm 24163, fols. 294v-297v; see Löbbert, 'Nachlass Lorenz Truchsess von Pommersfelden', esp. 127-132. The secondary literature on this chorus contains some errors. Löbbert, 'Nachlass Lorenz Truchsess von Pommersfelden', 131-132, referring to Renner, 'Gaudeamus omnes', 199-202, states that the melody of Emser's Epithalamia is based on the 'Introitus-Antiphon [sic] zum Allerheiligenfest', that is, Gaudeamus omnes, but this is not the case. Renner's article also contains some errors. He interpreted the snippet of the introit Gaudeamus omnes in a woodcut in Brant's Narrenschiff as a distortion of the chant melody for satirical effect. In the Liber usualis, the source Renner takes as authoritative, Gaudeamus has the pitches c- $\mathrm{d}-\mathrm{d}-\mathrm{a}-\mathrm{b} b=-\mathrm{a}$. The Narrenschiff woodcut has the notes $\mathrm{c}-\mathrm{d}-\mathrm{d}-\mathrm{a}-\mathrm{c}-\mathrm{a}$, which Renner interprets as a 'shocking' alteration that would be obvious to all. However, this melodic feature was typical of the German chant dialect. The reading of Gaudeamus omnes given in the Graduale Pataviense (Vienna: Winterburger, 1511), vdm 272, fol. 162 ${ }^{\mathrm{r}}$, agrees perfectly with that found in the woodcut. On this feature of the German chant dialect, see Hiley, Western Plainchant, 573.

25 Mundt, Lemnius und Luther, 1:105-108.

26 See for example Johann Nass, Quinta centuria, das ist/ das fünfft Hundert/ der Euangelischen Warheit (Ingolstadt: Alexander Weissenhorn, 1570), VD16 N 105, fols. 365 ${ }^{\mathrm{r}-\mathrm{v}}$; Maurice Hylaret, Sacrae decades quinquepartitae (Paris: Sébastien Nivelle, 1587), USTC 138169, 1:190-191; Johannes Theophilus Klibnitz, Christliches Sendschreiben an [. . .] Johann Georgen/ dem Andern/ Hertzogen zu Sachsen (Vienna: Leopold Voigt, 1671), VD17 12:111610F, fols. F4 ${ }^{\text {r-v }}$; Johann Nikolaus Weisslinger, Friß Vogel oder Stirb! (Strasbourg: Dietrich Lerse, 1722), not in VD18, 65; Eusebius Engelhard, Lucifer Wittenbergensis, oder der Morgen-Stern von Wittenberg (Landsberg: Johann Lorenz Singer, 1749), VD18 10787917, 2:125-129.

27 Eyn erschreglicher $\|$ wd doch widderumb kurtzweylliger ond nutzlich gesangk $\|$ der Lutziferischen ond Luttrischen kirchen/ auff dy $\|$ nachfolgend weyse durch eyn Euangelische ond $\|$ Apostolischen Prister ytzt zum nawen Jar \| der Christenheyt tzu heyl vnd seligkeyt \| auß gegangen. || [music] || Martinus hat gerathen Das Ri Rum Ritz. \| Man sal die pfaffen brathen Das Ri rum Ritz etc. \|M. R Syl. \| M.D.xxvj. ([Leipzig: Nickel Schmidt], 1526), vdm 695. Sylvius summarises this book in: Von den letzten Funff $\|$ buchern M. Petri Syluij [. . .] (Leipzig: Nickel Schmidt, 1528), VD16 P 1307, fol. C4v . An extract from text is edited in Neumann, Geistliches Schauspiel, 2:214-218. Further on Sylvius, see Seidemann, 'Die Schriften des Petrus Sylvius', esp. 13-15, 288-289, 302-306.

28 Clemen, 'Invictas Martini', showed that this parody first appeared as an appendix to Sendtbrieff. D. Andree Boden: von Carolstadt meldende seiner Wirtschafft/Newe getzeyt vonn pfaffen vnnd mönchenn zu Wittemberg außgangen (Wittenberg: [n. p.], [1522]), D-D1 Hist.eccl.E.243,16, not in VD16; later editions: VD16 B 6189-6194, ZV 2156.

29 Petrus Sylvius, Summa vnd schutz der $\|$ waren Euangelischen lere/ vnd der $\|$ gantzen Göttlichen schrifft/auffs newe gedrückt/gemehrt/ || ond gebessert [. . .] ([Leipzig]: [Nickel Schmidt and Valentin Schumann], 1529), VD16 
Martin has bidden that the priests should be roasted, the monks burned, and the nuns sent into the whorehouse. Kyrie eleison.

Sylvius answered these parodies with two of his own. In response to Invicti Martini laudes he wrote Convicti Lutheri fraudes exhorrent Christiani ('Christians shudder at the deceptions of the defeated Luther'). ${ }^{30}$ He countered Martinus hat gerathen with:

Christ hat gerathen/ vnd ernstlich gebothen.

Die Priesterschafft zu ehren/ vnd folgen ihrer lehren.

ky[rieleis]. ${ }^{31}$

Christ has bidden and earnestly commanded

that we should honour the priesthood and follow its teaching.

Kyrie eleison.

At New Year 1526, Sylvius published a pamphlet entitled On the identity of the Lutheran and Luciferian churches, in which he pointed out twenty-one similarities between the Lutheran church and the devil. ${ }^{32} \mathrm{He}$ may have been prompted to write this work as a response to a 1523 dialogue by Erasmus Alberus, in which Luther debates two devils dressed in monks' cowls. ${ }^{33}$ As a companion piece to this tract, Sylvius published a satirical song in which the devil and his hosts rejoice at the song Martinus hat gerathen and the harm it has done to the true church. In the preface, Sylvius explained that he was prompted to write this song by reports of the 'dumb Lutheran youth' who sang this blasphemous parody in beer halls. The song comprises a dialogue between an 'infernal chorus' ('der Hellische Chor') and Satan. The text was to be sung to a simple, mocking melody that, Sylvius tells us, was customarily used in plays when the infernal spirits sang to Lucifer. ${ }^{34}$ Sylvius reproduced the melody in mensural notation on the frontispiece of his pamphlet (Figure 9.5). Although the melody given by Sylvius is of the simplest kind, it is historically important, for it represents the only known notated example of the music sung in the devils' chorus, a stock scene in mediaeval religious drama. ${ }^{35}$

The demons sing that Luther is Satan's brother, who has fallen away from his vows and is now mired in lust and sin. Moreover, he attempts to seduce Christians from the right way, bringing to pass whatever Lucifer can invent ('Was Lutzifer kan erdencken | Das kan

P 1300, Appendix, fols. A1 ${ }^{\mathrm{v}}-2^{\mathrm{r}}$ : 'Darauff heb ich mit meynen ohren gehöret das sie auch vor [A2 ${ }^{\mathrm{r}}$ fünff iarn geßungen haben/ den nachfolgenden vnchristlichen deutschen text vff die weiß des österlichen geßanges / Christ ist erstanden [...]. Welcher Text als ichs von glawbwirdigenn gehorth/ hab/ ist erstlich geßungen worden in der löblichen vnd Christlichen stadt vortzeyten genanth Nurnbergk.' Sylvius, Eyn erschreglicher (1526), fol. A2 ${ }^{\mathrm{r}}$, gives the readings: 'Der Luther hat geratten' and 'Dy nonnen yns freyhauß furen'.

30 Sylvius, Summa ond schutz, fol. A2 ${ }^{\mathrm{r}}$.

31 Sylvius, Summa vnd schutz, fol. A4 ${ }^{\mathrm{r}}$.

32 Petrus Sylvius, Von der eynigkeit \| der Luttrischen vnd Lutziferischen kirche ond/| von yhrer gleychformiger arth ond eygenschafft $\|$ [. . . ] (Leipzig: Schmidt, Nickel, 1526), VD16 1309.

33 [Erasmus Alberus], Ain schoner Dialogus von Martino \| Luther vnd der geschickt pottschafft auß der helle die falsche $\|$ gaystligkayt vnd das wortt gots belangen $\|$ gantz hubsch zu lesen ([Erfurt]: [Michael Buchführer], 1523), VD16 A 1524.

34 Sylvius, Eyn erschreglicher (1526), fol. A1 v : 'So ich dan offt gehöret hab/ wie die Thumme Lutrische iugent in etlichen stedten/ Bo sy in byrheusern bey der kweßrey den hellischen geistern meßhalten/ pflegen tzu verachtung der Christlichen geistligkeyt tzu syngen den teuffels gesangk/ Luther hat gerathen \&c. auff den thon und weyse wie die hellischen laruen pflegen tzu syngen yhren Lutzifer Bo man yrgent ein spil übet. Nemlich Lutzifer in dem Throne/ das Ri Rum Ritz \&c. vnd nicht vnbekumlich/ dan wie die kirche ist/ Also sal auch sein der gesangk/ Der text/ die nothen und dy ßenger. Derhalben auff das dy Lutrische kirche/ vnd solchs teuffels gesinde/ sampt mit der Lutziferischen kirche/ eintrechtig vereyniget muchten mit eynander tzu gleych singen/ So hab ich auff dy selbige weyße noch mehr text gemacht/ darynn des Luthers vnd Lutzifers vereynigunge wird noch volkomlicher erklert.'

35 Neumann, 'Zeugnisse mittelalterlicher Aufführungen', 1:114-115. 


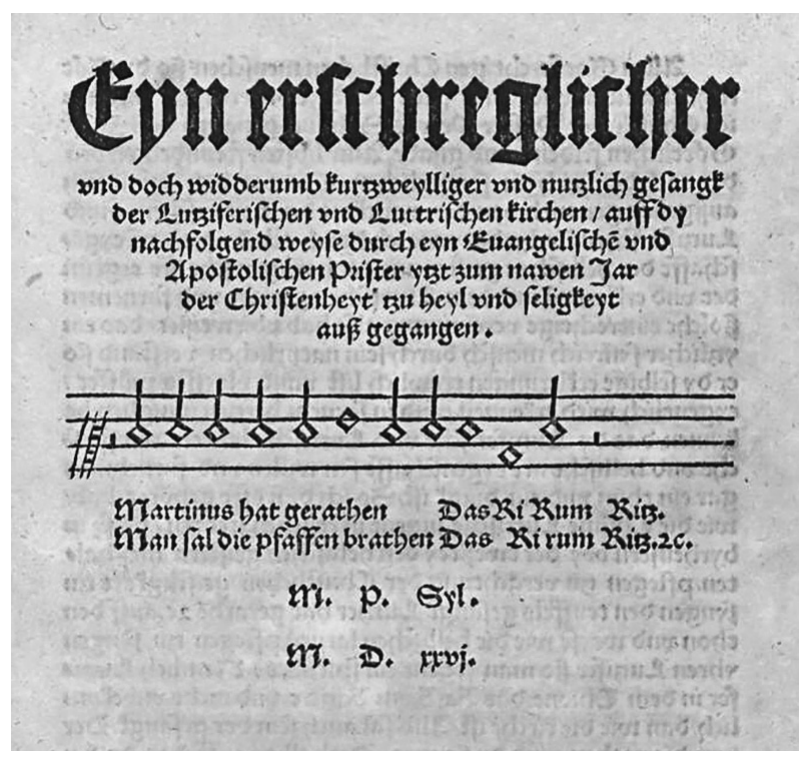

Figure 9.5 Petrus Sylvius, Eyn erschreglicher und doch widderumb kurtzweylliger und nutzlich gesangk. [Leipzig]: [Nickel Schmidt], 1526 (VD16 ZV 12265; vdm 695), fol. A1 ${ }^{\mathrm{r}}$

Source: Halle, Universitäts- und Landesbibliothek Sachsen-Anhalt, AB 153250 (6)

Luther auß schencken'). Satan's interventions are written in a different metre, and were perhaps spoken rather than sung. Some of Sylvius' claims were evidently not true, such as the notion that Luther advocated the abolishment of liturgical music ('Alles syngen vnd klingen | Das sall man gantz abdingen'). Despite all its crude satire and exaggeration, Sylvius' poem nevertheless expresses the fears and anxieties of those who remained true to the Roman church. Luther, they believed, encouraged the simple folk to disdain the praise of God and obedience to authority. He taught that bells, monstrances and chalices were to be melted down, and nuns sexually corrupted. Such actions could only bring the traditions of the church to ruin.

Sylvius' pamphlet comprises a single sheet, printed in quarto. The musical notation is cut quite carefully in wood. The printer did not identify himself, though Sylvius published most of his pamphlets with Nickel Schmidt following his move to Leipzig in August or September 1525. The typography of this edition is consistent with Schmidt's workshop. Curiously, Schmidt is known to have been a Lutheran; in 1524, he signed a petition requesting that the Leipzig city council allow Lutheran services in the city. However, his own evangelical faith evidently did not preclude him from printing tracts attacking Luther. Few printers in Leipzig could afford to turn away paid work in the 1520s, when the industry in the city was on the verge of collapse. Schmidt probably told himself that if he did not print Sylvius' pamphlets, one of his competitors would. ${ }^{36}$

Like Emser's Epithalamia, Sylvius' poem draws attention to Luther's perceived infractions of ecclesiastical order, and aims to forge group spirit by identifying and mocking a common enemy. In 1535, Sylvius reprinted a revised edition of his 1526 work on the Satanic nature of the Lutheran church, including the devil's chorus as an appendix, with the music printed

36 Reske, Buchdrucker, 518. 
from the same woodcut as the earlier edition. This later edition also has a title woodcut that depicts Luther and Satan holding hands to swear a compact (see Figure 9.2). The depiction of Luther, resting his left hand on a book as if to confirm the pact, derives from images from the Cranach workshop. Luther credulously extends his right hand while Satan offers only his left, thus deceiving Luther himself. Furthermore, the composition also recalls the iconography of a betrothal portrait, a monstrous marriage from which only ill could spring. In a parody of the iconography of Gregory the Great and the dove of the Holy Spirit, a small demon lifts the corner of Luther's doctoral biretta and whispers into his ear. The notion that Luther had entered into a pact with the devil was intended to disarm Luther's own identification of the Roman Catholic church as the antichrist. ${ }^{37}$

\section{$N u$ hört jr Christen newe meer and Mein himlischer vatter}

In early 1546, Luther travelled to Eisleben to adjudicate a dispute between rival factions in the ducal house of Mansfeld. There he suffered an attack of angina followed by cardiac arrest early on the morning of 18 January 1546. Justus Jonas, a theologian from Wittenberg who accompanied Luther on the journey, and Michael Coelius, pastor at Mansfeld, immediately sent an account of Luther's last days to Johann Friedrich of Saxony, including a transcript of his last words:

Da hat der herr doctor angefangen zu betten.

Mein himlischer vatter/ ewiger barmherziger Got/ du hast mir deinen lieben sohn/ vnsern herrn Jhesum Christum offenbart/ den hab ich gelert/ den hab ich bekant/ den liebe ich/ vnd den ere ich vor meinen lieben heilandt vnd erlöser/ welchen die gotlosen verfolgen/ schenden vnd schelten/ nim mein selichen zu dir.

In dem reth er in die drei mal/

In manus tuas commendo spiritum meum, redemisti me deus veritatis. Ja also hat Got die welt geliebt. ${ }^{38}$

Then Dr [Luther] began to pray: 'My heavenly father, eternal, merciful God, you have revealed to me your dear Son, our Lord Jesus Christ. I have taught about him, I have confessed him, I love him, and I honour him as my dear Saviour and Redeemer, whom the godless persecute, defile and abuse. Take my little soul to you.' Then he spoke three times: 'Into your hands I commend your spirit. You have redeemed me, o God of truth. God so loved the world, etc.'

This account spread quickly, and at least a half a dozen manuscript copies are extant. ${ }^{39}$ It received an even broader readership when it was printed in the pamphlet Drey Schrifften vonn des Eerwirdigen Herren Doctor Martin Luthers Christlichem abschied vnnd Sterben/ auch Eerlichem begrebnuß ([Augsburg]: [Steiner], 1546), in which Luther's prayer is highlighted through typographical means. This source evidently derives ultimately from the fair copy, since it includes an endorsement in Jonas' hand added to that copy, which assured the recipient that he had dictated the letter and that he and Coelius were present for the full duration of these events ('der bei disen allen gewesen'). A desire to have news from trustworthy eyewitness reports was a natural feature of early news networks, even before print, as Andrew Pettegree has shown. ${ }^{40}$

37 Langemeyer et al., Bild als Waffe, 163.

38 The draft is in Annaberg, Schulbibliothek; the fair copy is in D-WRl Reg. N 182, fols. $19^{\mathrm{r}}-2^{\mathrm{v}}{ }^{\mathrm{w}}$, here at fols. $20^{\mathrm{v}}-21^{\mathrm{r}}$, ed. Schubart, Berichte, 4-5. The diminutive 'selichen' in the Weimar ms is changed to 'Seel' in the early editions.

39 These sources are listed in Schubart, Berichte, 1. See also Pettegree, Brand Luther, 306-307.

40 Pettegree, The Invention of News, 2. 
After writing to the duke, Jonas wrote another letter to his colleagues in Wittenberg. On the morning of 19 January 1546, Philipp Melanchthon announced the contents of Jonas' letter to his class in Wittenberg, as one of his auditors related:

He told us that he had been advised to do so by the other professors for the reason that we, informed about the truth of the matter, might not embrace the many fictitious stories surrounding Luther's death which they knew would circulate here and there. ${ }^{41}$

While the idealised death described in the mediaeval ars moriendi emphasised the efficacy of the sacrament of extreme unction and the power of the administering priest, the various accounts of Luther's death that circulated in manuscript, and soon after in print, became a new Protestant norm that stressed the saving power of individual faith.

The Nuremberg cantor Leonhard Kettner wrote a versified account of Luther's death that ran through at least eleven editions between 1546 and 1549, in Upper German and Low German, chapbooks in octavo format, printed from a half-sheet. The edition printed at Wittenberg by Georg Rhau has a woodcut portrait of Luther on the cover, and contains the musical notation of the melody to which the ballad was to be sung: Johann Agricola's hymn Ich ruf zu dir, Herr Jesu Christ. (Most of the other editions simply specified this melody on their title pages without supplying the notation.) Kettner's versification of Luther's last words stretches over four stanzas. His account is clearly based on Jonas' report, from which it borrows words and even entire phrases. Direct verbal borrowings are indicated here in italics:

O Got Vater/ Herr Jesu Christi/ sprach er mit rechtem hertzen:|:

Hilf mir jtzund zu dieser frist/ vnd wende meinen schmertzen/

Dein Son hastu mir offenbart/

Von dem hab ich geleret/

In geehret/

Darinn kein müh gespart/

Also Bapsts lehr zerstöret.

Herr/ dein wort ich gepredigt hab/ welchs die Gottlosen schenden:\|:

Hab dauon nicht gelassen ab/ niemand kund das verwenden/

Du bist mein Herr mitten im tod/

Mein Erlöser/ mein Heiland/

Thu mir beystand/

O Herr/ O lieber Gott/

Mach mir jtzt dein Reich bekant.

Denn so hastu geliebt die Welt/ das du für Vns hast geben:\|:

Dein Son wer zjhm sein glauben stelt/ sol hab das ewig leben/

Zu dir/ Herr ich mein Hoffnung setz/

Herr dir thu ich vertrawen/

Auff dich bawen/

Das sag ich zu der letzt/

Dein angsicht las mich schawen.

41 Johannes Pollicarius, ed., HISTORIA $\|$ DE VITA ET ACTIS \| REVERENDISS. VIRI D. MART. | Lutheri, uerae Theologiae Doctoris, bo:\|na fide conscrip $=\|t a, \grave{a}\|$ PHILIPPO MELANTHONE [...] (Erfurt: Gervasius Sturmer, 1548), VD16 M 3416, E1 ${ }^{-}-2^{\mathrm{v}}$; also ed. in Schubart, Berichte, 22-24, from the 1549 reprint. This collection contains a number of documents relating to Luther's life and death, including Melanchthon's biography of Luther, an account of Luther's appearance at the Diet of Worms, and commemorative poems by Pollicarius and Georg Fabricius, collected by Johannes Pollicarius, pastor at Weissenfels. Pollicarius' preface is signed 20 October 1547. 
Zum bschlus/ sprach er/ Herr in dein hend/ ich dir meine Seel thu senden:\|:

Der wölstu gebn ein seligs end/ dein gnad nicht von mir wenden/

Herr mich allein befihl ich dir/

In deim Nam will ich sterben/

Vnd ererben/

Was du hast zugsagt mir/

Dein ewig Reich erwerben. ${ }^{42}$

'O Father God, Lord Jesus Christ,' he spoke with right heart, 'Help me now and turn away my pain. You have revealed your Son to me, I taught of him and honoured him, saving no pains, and thus destroyed the Pope's doctrine.

Lord, I preached your Word, which the godless defile, and did not desist, and no one could refute that. You are my Lord in the midst of death. My redeemer, my saviour, bear me up! O Lord, o dear God, show me your kingdom now.

For you so loved the world, that you gave your Son for us, that whoever believes in him should have everlasting life. In you, o Lord, do I trust and build. And at the last I say, let me see your face.'

And at the end he spoke, 'Lord, into your hands I commend my spirit. Give me a blessed end, and do not turn your grace away from me. Lord, I commit myself to you alone. I want to die in your name and inherit what you have promised me: to gain your eternal kingdom.'

The report of Luther's death, as made by eyewitnesses and implicitly endorsed through the fact that it was published at Wittenberg, travelled through Germany in Jonas' prose account and Kettner's ballad, carried along on the back of a familiar melody. Kettner's ballad was reprinted as late as 1549, and Jonas' account as late as 1555, long after the event had ceased to be news. Such postponed editions suggest that readers valued the accounts of Jonas and Kettner as a new kind of ars moriendi.

The news of Luther's death prompted an outpouring of grief among his followers. The composer Caspar Othmayr wrote a Latin poem in elegiacs reflecting on the event:

Per quem salvifici redierunt dogmata Christi, Hic vermes (ut habent fata) Lutherus alit.

Tutus ab insidiis, et casu tutus ab omni, Spiritus in coelis vivit, et astra videt.

Luther, through whom the teachings of our Saviour Christ returned, Here feeds the worms, as fate demands.

Safe now from all intrigues and all reverses of fortune,

His spirit lives in the heavens, and beholds the stars.

Othmayr also set this text to music, once again in the third and fourth tones (transposed). ${ }^{43}$ Typical of Othmayr's humanistic approach is his close attention to verse metre. The piece was printed in a set of partbooks containing only two pieces, both relating to the death of Luther. ${ }^{44}$ The polyphonic lament is closely related to the literary genre of the classical epicedion and the mediaeval planctus or déploration. In late sixteenth-century Germany, musical laments are often found in conjunction with funeral sermons, which were invariably

42 Leonhard Kettner, Von D. Mar\|tini Luthers sterben/Ein \|schön new Lied/darinn kürtz=\|lich begriffen/was er jn der letz=\|ten zeit geredt/sehr tröstlich \|allen Christen [. . ] (Wittenberg: Rhau, 1546), vdm 1037, fols. A2 ${ }^{\mathrm{v}}-3^{\mathrm{r}}$; further editions: VD16 K 846; K 848; K 849; K 850; K 851; K 852; ZV 26007; ZV 22180; ZV 8922; ZV 21593. Brednich does not list the Wittenberg edition. Kettner's poem is not noted in Schubart, Berichte.

43 Othmayr's versification is reasonably correct, apart from the infelicitous caesura in v. 2.

44 EPITAPHIVM || D. MARTINI LVTHERI,\| A GASPARE OTMAIER \| Musicis Elegijs redditum.|| TENOR (Nuremberg: Berg and Neuber, 1546), vdm 1038. 
accompanied by celebratory and commemorative poems on the deceased. Melanchthon's funeral sermon for Luther, often printed with Jonas' letter describing Luther's death, was one of the first examples of this genre. Othmayr's short collection thus straddles two print genres: the printed collection of polyphonic music, and the printed funeral sermon. This double function is clear on the title page, in which the generic function EPITAPHIVM and the name of the subject D. MARTINI LVTHERI vie for typographical prominence with the voice designation TENOR.

The other piece printed in Othmayr's collection Epitaphium D. Martini Lutheri is a polyphonic setting of Luther's last prayer, as reported in Justus Jonas' initial letter to Johann Friedrich. (Most other printed editions rely on slightly later reports, and give a slightly different text of the prayer.) Othmayr's five-voice setting, set once again in the third and fourth tone, transforms a narrative element from Jonas' report into an element of musical structure. According to Jonas, Luther three times spoke the words, 'Into thy hands I commend my spirit; you have redeemed me, o God of truth.' This text, taken from Psalm 30:6, was the responsorium breve for compline. Othmayr took the relevant chant as his cantus firmus, repeating it three times, as in Jonas' account. Its appearance is highlighted by the introduction of e-flats in the other voices, to accommodate the b-flats in the cantus firmus (Example 9.4).

Othmayr's collection thus contains two pieces united by their theme, but distinct in other ways. The first piece is in Latin, and is free-composed. The second is in German, but contains a cantus firmus in Latin. This latter piece thus renders Luther's own vigorous bilingualism, which has been explored by Birgit Stolt. ${ }^{45}$ Othmayr's purpose in publishing a setting of Luther's last words is perhaps not immediately obvious. It might be argued that this setting had the function of spreading the report of Luther's death. However, by the time he came to write this piece, this was not exactly breaking news. It seems more likely that the piece has a commemorative or even devotional function, like those editions of the reports of Luther's death that appeared years after the event. Furthermore, humanist composers enjoyed setting the last words (novissima verba) of famous personages, a summa of their life, a musical analogue to the death mask or deathbed portrait. Settings of Dulces exuviae, the last words of Dido as reported in Vergil's Aeneid, constitute a subgenre among sixteenthcentury secular motets. ${ }^{46}$ Othmayr was attracted by the idea of summarising an individual's personality and achievements in a self-contained motto-composition or symbolum, and in 1547 he published a volume of thirty-four such motto-pieces, including one for Luther.

Besides this commemorative function, it is suggested that this setting of Luther's last words also has an apologetic, even polemical function. Evidence for this contention may be found in Othmayr's next collection, Cantilenae aliquot elegantes ac piae (Nuremberg: Berg \& Neuber, 1546). ${ }^{47}$ The preface, dated 6 October 1546, was contributed by Veit Dietrich, Lutheran pastor in Nuremberg. Dietrich referred to Jonas' report of Luther's last days. He was dismayed by the response of Roman Catholic controversialists to the reformer's death, especially the sarcastic references to Luther as the 'prophet of Germany'. (Dietrich is probably referring to Georg Witzel's 1546 tract The reasons for the long-standing calamity

45 Stolt, Die Sprachmischung in Luthers Tischreden.

46 Strunk, 'Vergil in Music', p. 489; Guentner, 'Dulces exuviae in Sixteenth Century Music'.

47 CANTILENA $\|$ ALIQVOT ELEGAN-\|TES AC PIAE, QVIBVS HIS TVR $\#$ |bulentis temporibus Ecclesia Christi utitur.|| Musicis harmonijs ornatæ, à Gaspare Othmayer (Nuremberg: Berg \& Neuber, 1546), vdm 1039.

48 Georg Witzel, CAVSA || TAM DIVTVRNAE || CALAMITATIS ECCLE |SIASTICI STATVS || IN GERMANIA.|| D. Gersonites Landauus (Cologne: Quentel's heirs, 1546), VD16 W 3889, fols. B3 ${ }^{\text {r-v }}$. 
of the state of the church in Germany. ${ }^{48}$ ) Dietrich defended Luther's prophetic status against such attacks, comparing his prophetic gifts to those of Elijah. In Dietrich's opinion, hymns such as Erhalt uns Herr and Verleyh uns freiden revealed their prophetic significance in the chaos following Luther's death. Dietrich praised Othmayr's settings of these hymns, describing him a 'learned musician' ('eruditus Musicus') and 'a very diligent student of true piety' ('pietatis verae perstudiosus'). ${ }^{49}$ Given that Othmayr asked Dietrich to contribute this preface, we can probably assume that they shared similar views about the importance of vindicating Luther's memory against the calumnies of his opponents.

But perhaps we can go even further. The mediaeval tradition of the ars moriendi emphasised that the attitude, actions and words of the dying, as well as the intercession of their friends and the attending priest, would decide whether their soul would be dragged down to hell by demons, or ushered on to purgatory by angels. For decades following Luther's death, Roman Catholic controversialists circulated rumours about this event that reflected their own theological preoccupations. Tommaso Bozio (1591) wrote: 'Luther's servant, who later converted to the true faith, affirmed that Luther, after eating a hearty dinner, was that same night agitated by despair and the furious onslaught of a demon, and hanged himself. ${ }^{50}$ Nicolaus Serarius (1599) went even further:

Though it is clear that Luther was carried off in a sudden and unprepared death, others are of another opinion, but many people believe that he was slain by his evil demon, since the physicians called to attend him either said that they did not know what his illness was, or pretended that it was a stroke..$^{51}$

Such sudden death, bereft of the assistance of priest or sacraments, was just about the worst thing a Roman Catholic theologian could imagine. The assumption made by Bozio and Serarius that Luther was driven to his death by demons is consistent with the imagery, both verbal and iconographical, of Sylvius' broadsheet. Accordingly, I suggest that Othmayr's intention was not simply to commemorate and mourn Luther's death. Rather, like Melanchthon announcing Luther's death to his students, Othmayr wished to anticipate rumours that Luther's death was violent, frightening and moreover demonic by emphasising the tone of serenity, deep faith and faithfulness to the Scriptures, evident both in Jonas' account of Luther's final prayer and in Othmayr's music. The same impression of peaceful departure is given by the multiple images of Luther's deathbed portrait manufactured in the Cranach workshop after an eyewitness sketch by Lucas Furtenagel, and distributed widely. ${ }^{52}$ In many of these portraits, the reformer's unmistakeable features are surrounded by a kind of halo or nimbus created by the pillow on which his head rests.

49 Dietrich's preface is reprinted in Othmayr, Ausgewählte Werke, 5-6.

50 Tommaso Bozio, DE SIGNIS \| ECCLESIAE DEI | LIBRI XII [ . . .] (Rome: Donangeli, 1591), USTC 816657, 2:514: 'Lutherum cùm vespere lautè coenasset, ac laetus somno se dedisset, ea nocte suffocatus interiit. Audiui haud ita pridem compertum testimonio sui familiaris, qui tum puer illi seruiebat, \& superioris annis ad nostros se recepit, Lutherum sibimet ipsi laqueo iniecto necem miserrimam attulisse; sed datum protinus cunctis domesticis rei consciis iusiurandum, ne factum diuulgarent, ob honorem adiecere Euangelij.' The story was later related by Cornelius a Lapide, Commentaria in epistolas canonicas (Lyon: Prost, 1627), 364.

51 Nicolaus Serarius, IN SACROS $\|$ DIVINORVM $\|$ BIBLIORVM $\|$ LIBROS, $\|$ TOBIAM, IVDITH, E ESTHER, MACHABAEOS, „| Commentarius [. . .] (Mainz: Lippius, 1599), VD16 ZV 1810, 112: 'Lutherum vero subitanea \& improuisa morte sublatum cum liqueat, alij quidem aliter, sed plurimi suo à cacodaemone peremtum existimant, cum vocati ad eum Medici morbum vel ignorare se faterentur, vel apoplexiam fingerent.'

52 Dresden, Staatliche Kunstsammlungen, inv. GG1955; Hannover, Niedersächsisches Landesmuseum, inv. KM107; Karlsruhe, Staatliche Kunsthalle, inv. 0121. 


\section{Conclusion}

All the settings discussed here present a picture of Luther that is highly subjective and moulded to polemical ends. The Luther who emerges is not a regular man, but one who dwelt on the level of the saints - or demons. The deployment of such imagery was partly Luther's own invention. He constantly referred to the papacy as the Antichrist, a title taken from the book of the Apocalypse. Many of his best known hymns, such as Christ lag in Todes Banden, contain violent imagery of cosmic strife. Such imagery implied that the Reformation of the church (or its deformation, depending on one's own perspective) had cosmic consequences. Each of the pieces we have examined presents a different image of Luther. Each make claims to credibility, but each is carefully crafted and even distorted to a greater or lesser degree in order to represent the interests of those who imagined him capering below with the demons, or resting peacefully in anticipation of the Last Day.

\section{References}

Bauch, Gustav. 'Zu Christoph Scheurls Briefbuch'. Neue Mitteilungen aus dem Gebiet historischantiquarischer Forschungen 19 (1898): 400-456.

Brednich, Rolf Wilhem. Die Liedpublizistik im Flugblatt des 15. bis 17. Jahrhunderts. 2 vols. Baden-Baden: Koerner, 1975.

Brinkhus, Gerd. 'Die Bücherstiftung Konrad Hagens für die Universität Tübingen im Jahre 1559: Eine Studie zum ältesten erhaltenen Bestand der Tübinger Universitätsbibliothek'. Bibliothek und Wissenschaft 14 (1980): 1-109.

Clemen, Otto. 'Andreas Frank von Kamenz'. NASG 19 (1898): 95-115.

Clemen, Otto. 'Beiträge zur Lutherforschung 3.VII'. Zeitschrift für Kirchengeschichte 36 (1916): 113-122.

Clemen, Otto. 'Invictas Martini laudes intonent Christiani'. Archiv für Reformationsgeshichte 2 (1904/5): 685-690.

Creizenach, Theodor. 'Das "Gaudeamus" und was daran hängt'. Verhandlungen deutscher Philologen und Schulmänner 28 (1873): 203-207.

Dürer, Albrecht. Tagebuch, in Schriftlicher Nachlass. Edited by Hans Rupprich. 3 vols. Berlin: Deutscher Verein für Kunstwissenschaft, 1956-1969.

Eisermann, Falk. 'Auflagehöhen von Einblattdrucken im 15. und frühen 16. Jahhundert'. In Einblattdrucke des 15. und frühen 16. Jahrhunderts: Probleme, Perspektiven, Fallstudien, edited by Volker Honemann et al., Tübingen: Max Niemeyer, 2000: 143-177.

Estreicher, Karol Józef Teofil. Bibliografia polska. Kraków: Wyd. Tow. Naukowego Krakowskiego.

Griese, Sabine. 'Sammler und Abschreiber von Einblattdrucken. Überlegungen zu einer Rezeptionsform am Ende des 15. und Anfang des 16. Jahrhunderts'. In Humanismus und früher Buchdruck, Pirckheimer-Jahrbuch 11, edited by Stephan Füssel and Volker Honemann. Nuremberg: Carl, 1996: 43-69.

Guentner, Francis J. 'Dulces exuviae in Sixteenth Century Music'. The Classical Journal 68 (1972): 62-67.

Heider, Andreas. Spolia vetustatis: Die Verwandlung der heidnisch-antiken Tradition in Jakob Baldes marianischen Wallfahrten. Munich: Herbert Utz, 1999.

Hiley, David. Western Plainchant: a Handbook. Oxford: Oxford University Press, 1993.

Hoffmann von Fallersleben, August Heinrich. Gaudeamus igitur: eine Studie, 2nd edn. Halle: Schwetschke, 1872.

Köstlin, Julius. 'Johann Heß, der Breslauer Reformator'. Zeitschrift des Vereins für Geschichte und Alterthum Schlesiens 6 (1854): 97-131, 181-265.

Langemeyer, Gerhard, Monika Arndt, and Jürgen Döring, eds. Bild als Waffe: Mittel und Motive der Karikatur in fünf Jahrhunderten. Munich: Prestel, 1985. 
Leppin, Volker and Gury Schneider-Ludorff, eds. Das Luther-Lexikon. Regensburg: Bückle \& Böhm, 2014.

Löbbert, Bernhard. 'Über den schriftlichen Nachlass des Lorenz Truchsess von Pommersfelden (1473-1543)'. Archiv für mittelrheinische Kirchengeschichte 60 (2008): 111-132.

Malagola, Carlo. Della vita e delle opere di Antonio Urceo detto Codro studi e ricerche. Bologna: Garagni, 1878.

Mundt, Lothar. Lemnius und Luther: Studien und Texte zur Geschichte und Nachwirkung ihres Konflikts (1538/39). Bern: Peter Lang, 1983.

Neumann, Bernd. 'Zeugnisse mittelalterlicher Aufführungen im deutschen Sprachraum: eine Dokumentation zum volkssprachigen geistlichen Schauspiel'. PhD dissertation, Universität Köln, 1979.

Neumann, Bernd. Geistliches Schauspiel im Zeugnis der Zeit. Munich: Artemis, 1987.

Othmayr, Caspar. Ausgewählte Werke, Zweiter Teil. Edited by Hans Albrecht. Frankfurt: Peters, 1956.

Pettegree, Andrew. Brand Luther: 1517, Printing, and the Making of the Reformation. New York: Penguin, 2015.

Pettegree, Andrew. The Invention of News: How the World came to know about itself. New Haven, CT: Yale University Press, 2014.

Renner, Hans-Georg. 'Gaudeamus omnes. Ein früher musikalischer Spaß? Anmerkungen zur närrischen Musik bei Sebastian Brant'. Annuaire de la Société des amis de la Bibliothèque de Sélestat 2006: 199-202.

Reske, Christoph. Die Buchdrucker des 16. und 17. Jahrhunderts im deutschen Sprachgebiet. Wiesbaden: Harrassowitz, 2007.

Röckelein, Hedwig, Berndt von Egidy, Joachim-Felix Leonhard and Gerd Brinkhus. Die lateinischen Handschriften der Universitätsbibliothek Tübingen, Teil 1: Signaturen Mc 1 bis Mc 150. Wiesbaden: Harrassowitz, 1991.

Roper, Lyndal. 'Martin Luther's Body. The "Stout Doctor" and His Biographers'. American Historical Review 115 (2010): 350-384.

Rowland, Ingrid D. 'Revenge of the Regensburg Humanists, 1493'. Sixteenth Century Journal 25 (1994): 307-322.

Ruland, Anton. 'Die Original-Ausgabe der "Epithalamia Martini Lutheri"'. Serapeum 19 (1858): 7-10.

Schubart, Christoph. Die Berichte über Luthers Tod und Begräbnis. Texte und Untersuchungen. Weimar: Böhlau, 1917.

Seidemann, Johann Karl. 'Die Schriften des Petrus Sylvius'. Archiv für Litteraturgeschichte 5 (1876): 6-32, 287-310.

Steiff, Karl. 'Zur Entführung Luthers auf die Wartburg'. Theologische Studien aus Württemberg 9 (1888): 210-212.

Stolt, Birgit. Die Sprachmischung in Luthers Tischreden. Studien zum Problem der Zweisprachigkeit. Uppsala: Almqvist \& Wiksell, 1964.

Strunk, W. O. 'Vergil in Music'. Musical Quarterly 16 (1930): 482-487.

Wagner Oettinger, Rebecca. Music as Propaganda in the German Reformation. Aldershot: Ashgate, 2001.

Weale, William Henry James and Hanns Bohatta. Bibliographia liturgica: Catalogus missalium ritus latini ab anno MCCCLXXV impressorum. London: Quaritch, 1928.

Wiedemann, Theodor. Johann Eck, Professor der Theologie an der Universität Ingolstadt. Regensburg: Pustet, 1865.

Wilczek, Piotr. (Mis)translation and (Mis)interpretation: Polish Literature in the Context of Cross-Cultural Communication. Frankfurt am Main: Peter Lang, 2005. 

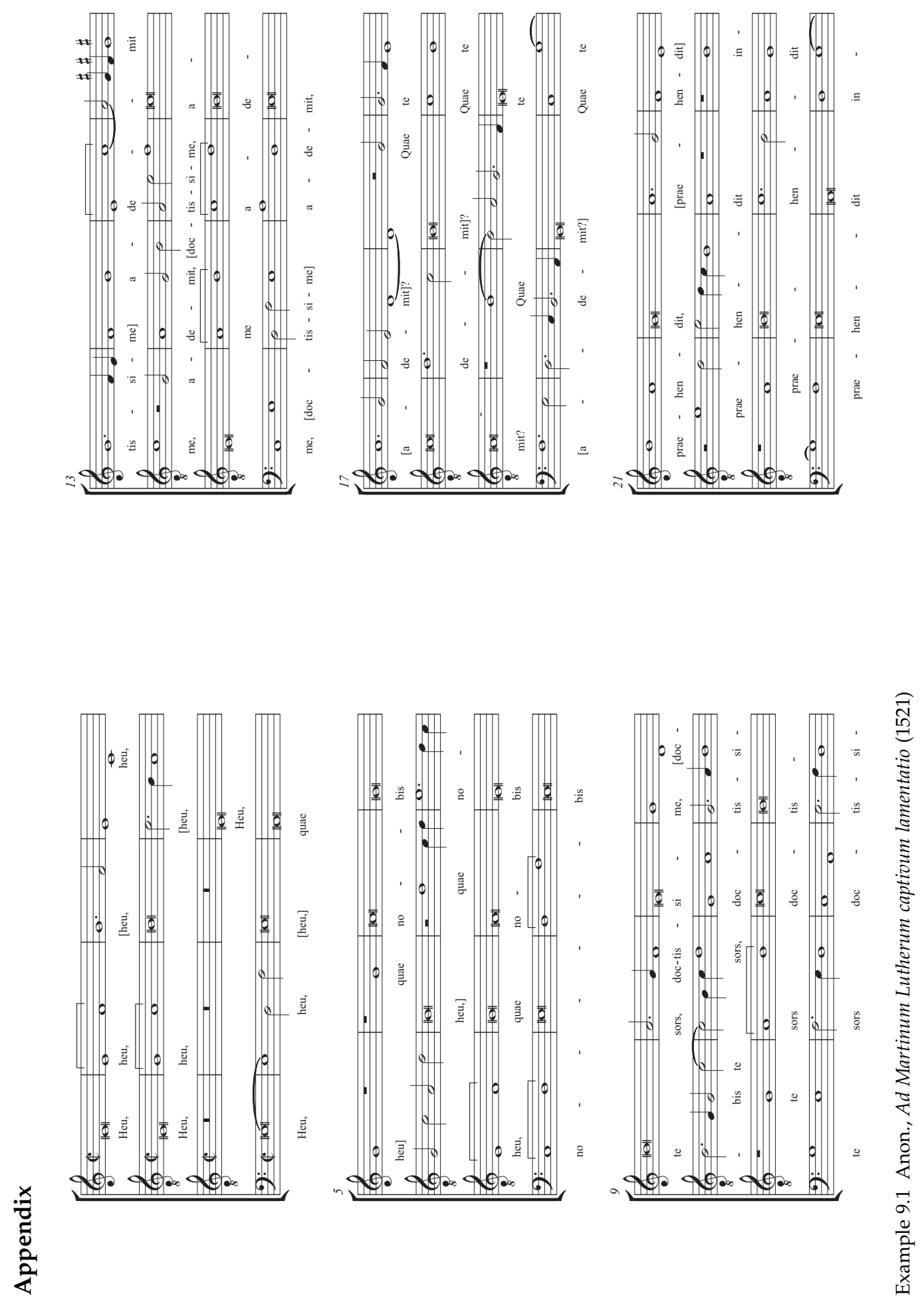

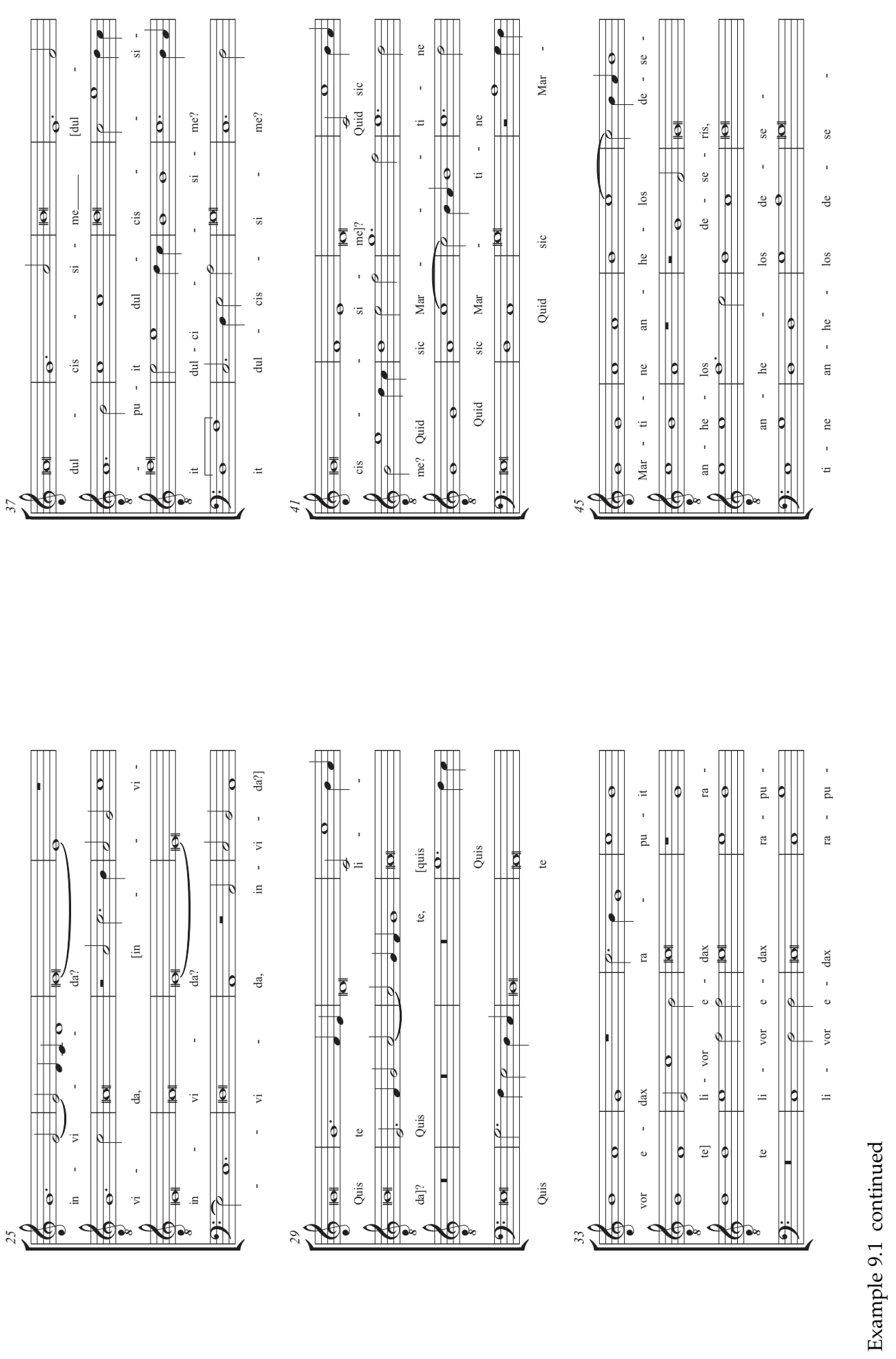

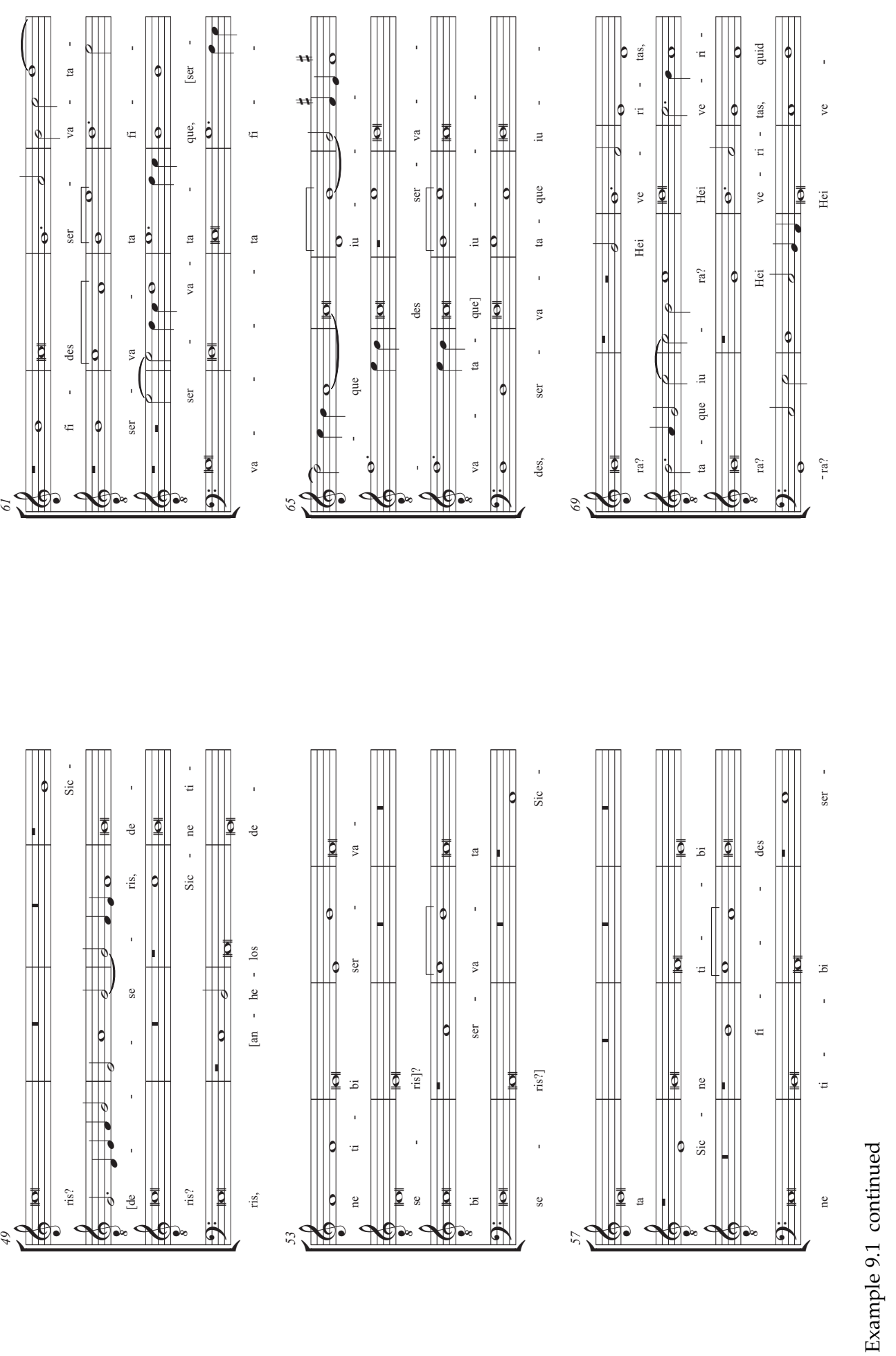

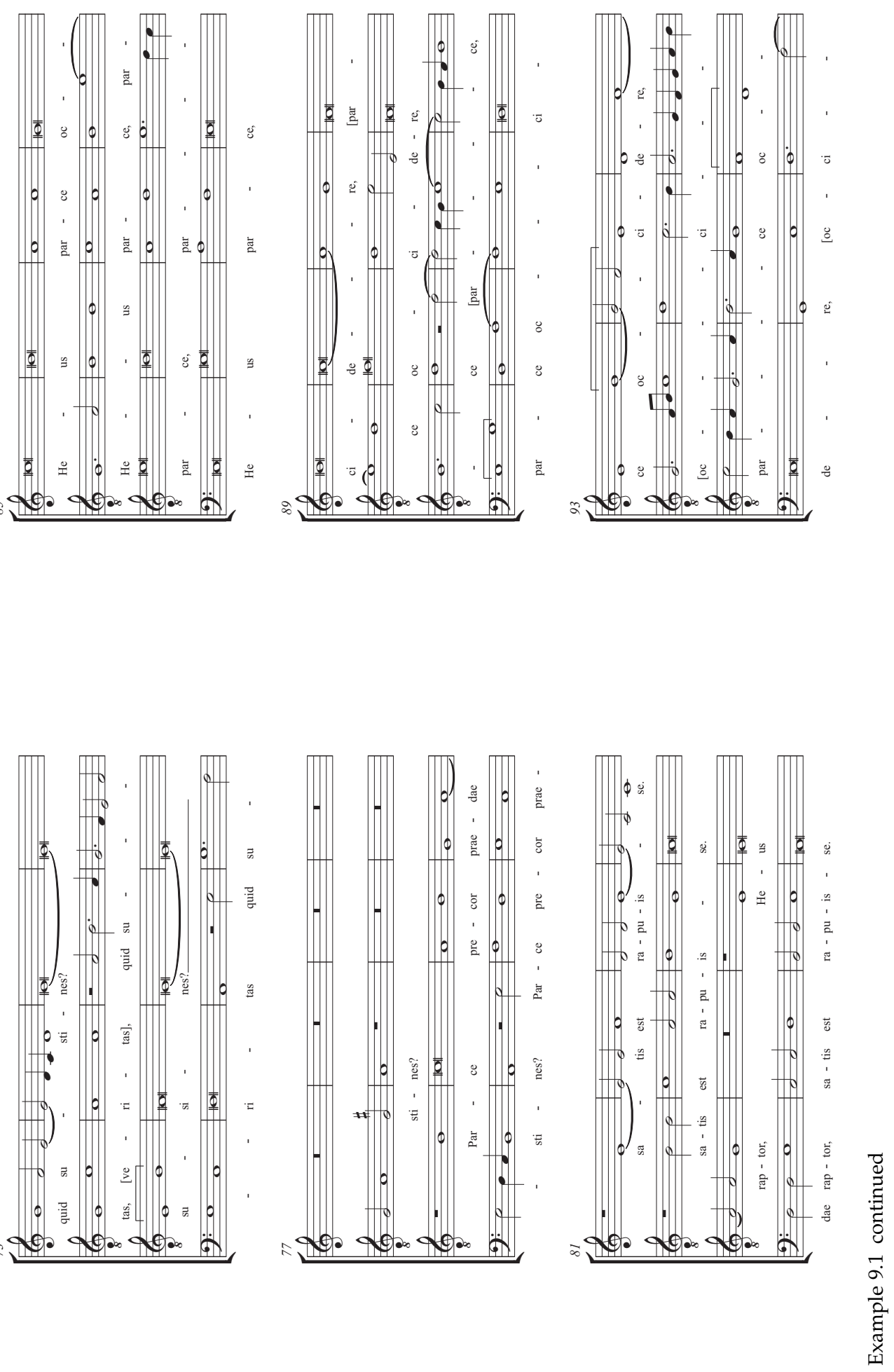

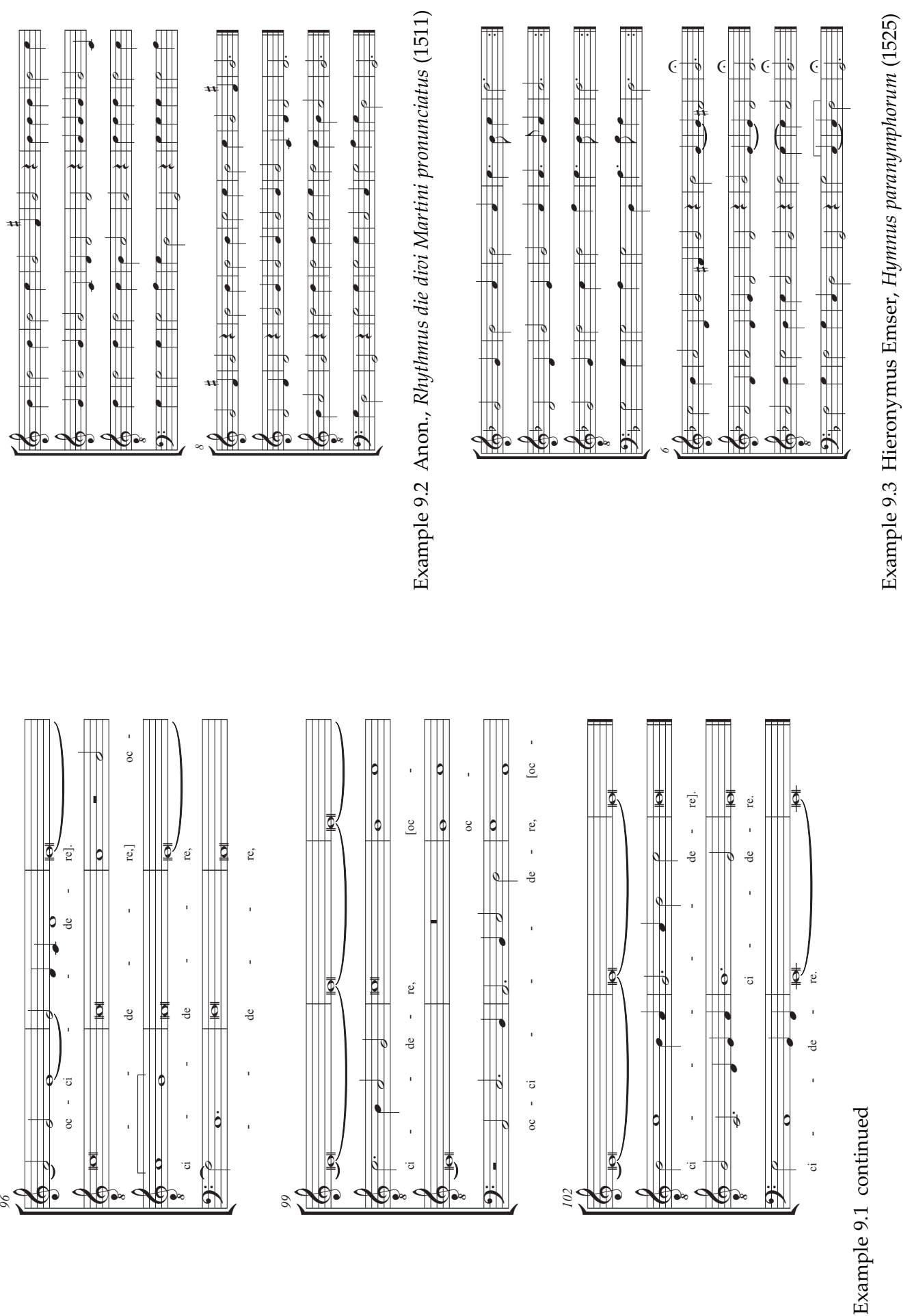

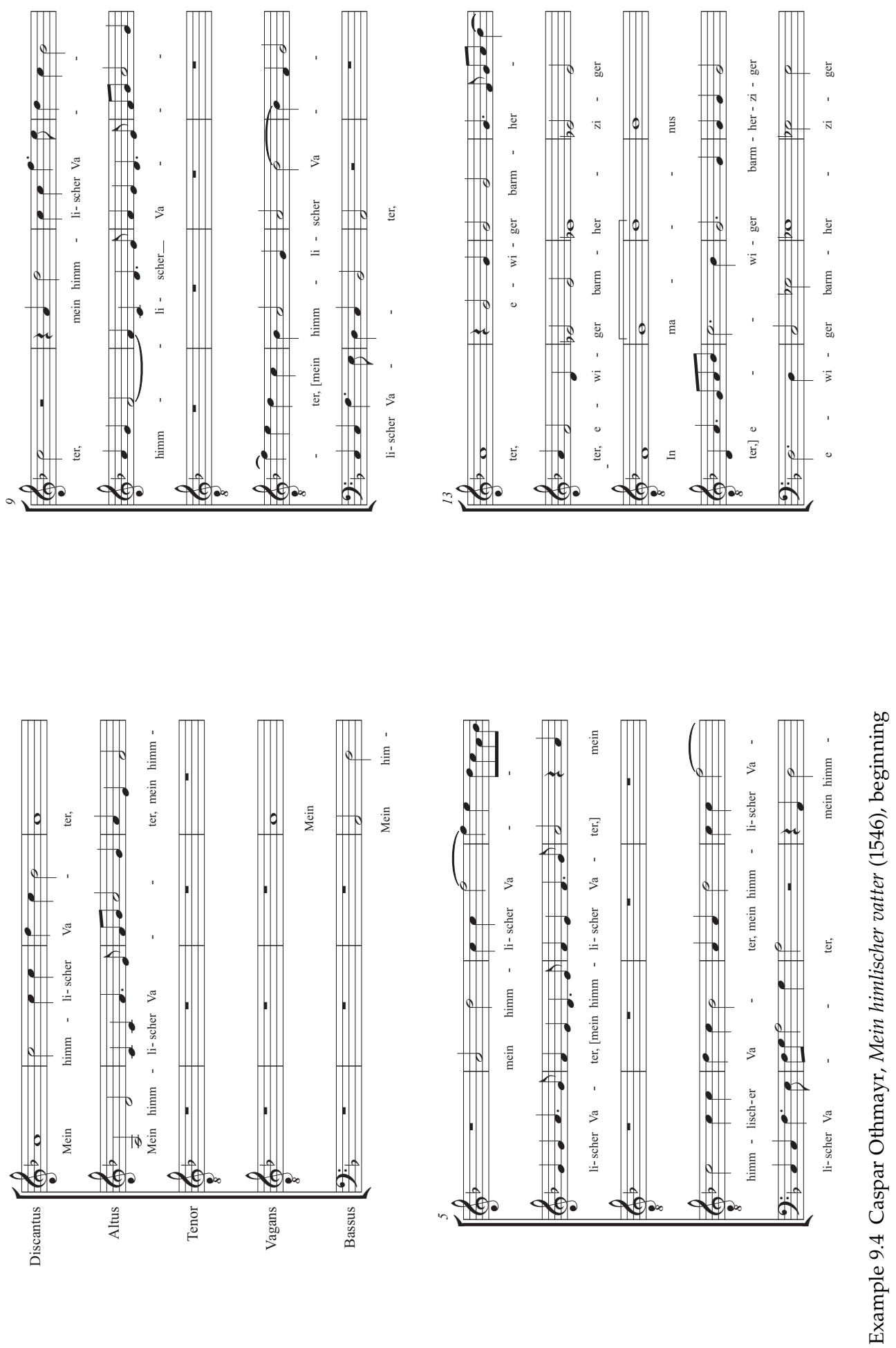

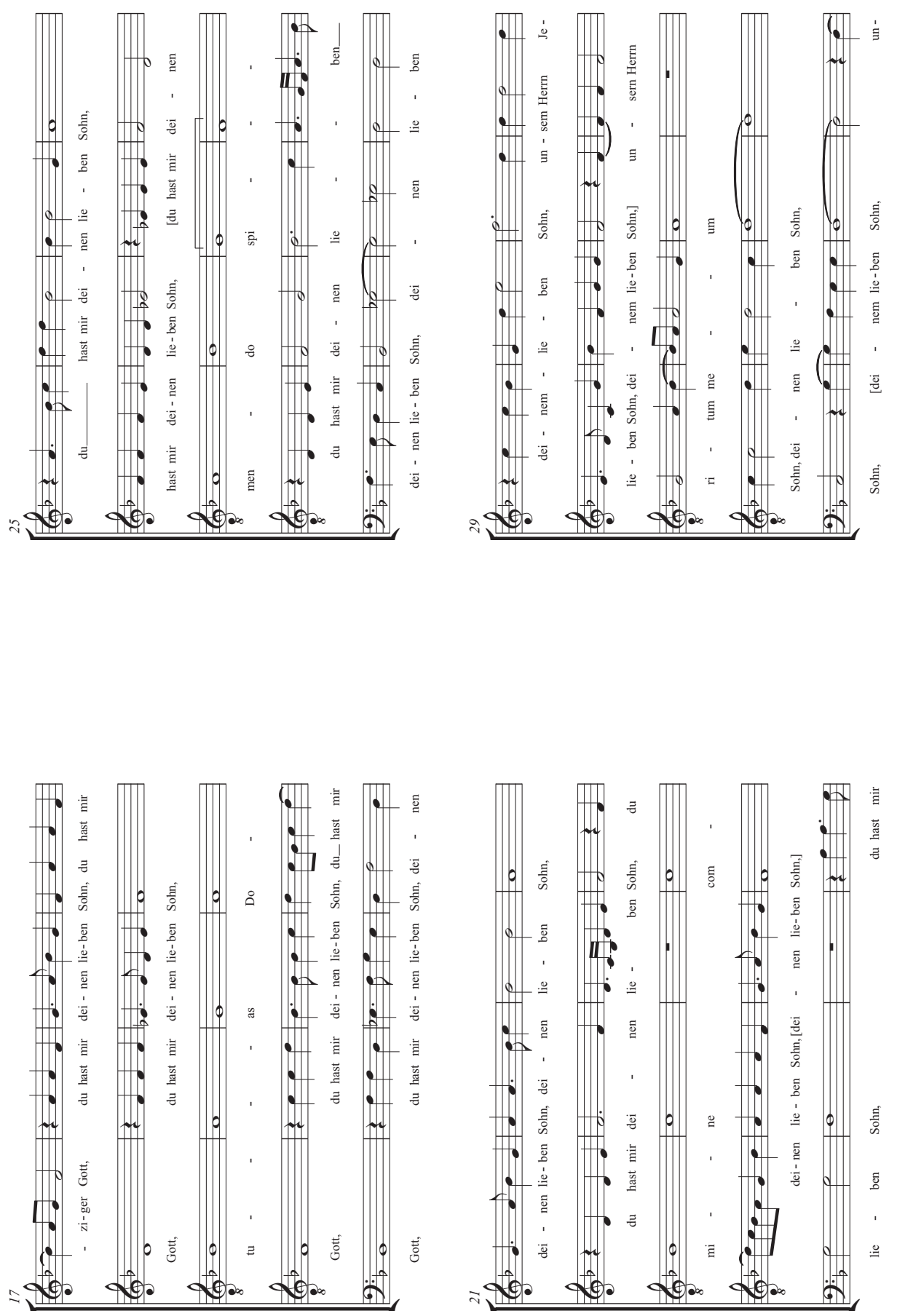

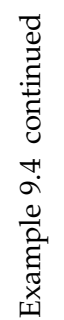

